\title{
Filling the gap: new precise Early Cretaceous radioisotopic ages from the Andes
}

\author{
BEATRIZ AGUIRRE-URRETA*†, MARINA LESCANO*, MARK D. SCHMITZ \\ MAISA TUNIK $\S$, ANDREA CONCHEYRO*, PETER F. RAWSONף\| \\ \& VICTOR A. RAMOS* \\ *Instituto de Estudios Andinos Don Pablo Groeber (UBA-CONICET), Universidad de Buenos Aires, Ciudad \\ Universitaria, pabellón 2, 1428 Buenos Aires, Argentina \\ $\ddagger$ Department of Geosciences, Boise State University, 1910 University Drive Boise, Idaho, ID 83725, USA \\ §Universidad de Río Negro, Sede Alto Valle, General Roca, Río Negro, Argentina \\ TCentre for Environmental and Marine Sciences, University of Hull (Scarborough Campus), Filey Road, Scarborough, \\ North Yorkshire YO11 3AZ \\ ||Department of Earth Sciences, University College London, Gower Street, London WC1E 6BT, UK
}

(Received 5 July 2014; accepted 15 December 2014)

\begin{abstract}
Two tuffs in the Lower Cretaceous Agrio Formation, Neuquén Basin, provided $\mathrm{U}-\mathrm{Pb}$ zircon radioisotopic ages of $129.09 \pm 0.16 \mathrm{Ma}$ and $127.42 \pm 0.15 \mathrm{Ma}$. Both horizons are well constrained biostratigraphically by ammonites and nannofossils and can be correlated with the 'standard' sequence of the Mediterranean Province. The lower horizon is very close to the base of the Upper Hauterivian and the upper horizon to the Hauterivian/Barremian boundary, indicating that the former lies at c. $129.5 \mathrm{Ma}$ and the latter at c. $127 \mathrm{Ma}$. These new radioisotopic ages fill a gap of over 8 million years in the numerical calibration of the current global Early Cretaceous geological time scale.
\end{abstract}

Keywords: Neuquén Basin, Hauterivian, biostratigraphy, ammonoids, calcareous nannofossils, U-Pb CA-ID-TIMS, Argentina.

\section{Introduction}

The Geological Time Scale for the Phanerozoic has one of its last geochronological gaps in the latest Jurassic - Early Cretaceous interval, where no precise radioisotopic ages are available (Fig. 1) (Cohen et al. 2013). The global Lower Cretaceous 'standard' subdivisions (stages) are based on sequences in the Mediterranean Province of the Tethyan Realm and are currently defined by biostratigraphic markers, especially ammonites and calcareous nannofossils (e.g. Channell et al. 2010; Wimbledon et al. 2011; Reboulet et al. 2014; Aguado et al. 2014). Unfortunately, one of the main problems is that in most areas where such good biostratigraphic control exists, there are few suitable rocks for modern highprecision geochronology, for example by chemical abrasion isotope dilution thermal ionization mass spectrometry (CAID-TIMS) $\mathrm{U}-\mathrm{Pb}$ zircon dating techniques. As a result, the exact age of stage and substage boundaries remains uncertain (Fig. 1).

$†$ Author for correspondence: aguirre@gl.fcen.uba.ar
Most of the previous tentative numerical age tie-points in the Early Cretaceous (Berriasian-Barremian) of Tethys are indirect, and based upon the correlation of biostratigraphic data with magnetic chrons, which, in turn, have very poor and controversial time controls for this time span (see Channell et al. 2010; Ogg \& Hinnov, 2012a). Some approaches have focused mainly on the Pacific sea-floor spreading numerical model of the M-sequence magnetic-polarity pattern and from limited recent cyclostratigraphic studies (Gradstein et al. 2012). Other authors combined robust nannofossil biostratigraphy and cyclostratigraphy to constrain the numerical dates for stage boundaries based on the accepted magnetochron ages (Sprovieri et al. 2006).

Wan et al. (2011) studied Lower Cretaceous strata exposed in southern Tibet in order to identify the Jurassic/Cretaceous $(\mathrm{J} / \mathrm{K})$ boundary using calcareous nannofossil assemblages and to constrain the age of Valanginian nannofossils with $\mathrm{U}-\mathrm{Pb}$ SHRIMP zircon dating. Based on a single date from a rhyolite, they proposed that the numerical age of the Valanginian/Hauterivian boundary should be no older than $136 \pm 3.0 \mathrm{Ma}$ and, by considering sedimentary accumulation rates in the studied sections, the $\mathrm{J} / \mathrm{K}$ boundary was estimated to be $145 \mathrm{Ma}$. More recently, Liu et al. (2013) working also in the same general area of Tibet, studied ammonites and nannofossils, integrating their biostratigraphic results with four U-Pb SIMS zircon ages. Their main conclusion was that the J/K boundary should be older that 141-142 Ma.

The first attempt to combine robust biostratigraphic control provided by ammonites and calcareous nannofossils with high-precision CA-ID-TIMS zircon ages was published by Vennari et al. (2014) for the $\mathrm{J} / \mathrm{K}$ boundary in the Neuquén Basin, a predominantly marine retro-arc basin (Fig. 2a) in the foothills of the Argentine Andes. Higher in the Neuquén sequence, episodic pyroclastic deposits are interbedded with fossiliferous dark shales and limestones of Hauterivian age in the upper part of the Agrio Formation. The ammonite and calcareous nannofossil sequences here are well documented and can be correlated confidently with the 'standard' Mediterranean sequence (Section 4 below). A previous study (Aguirre-Urreta et al. 2008) combined this robust biostratigraphy with $\mathrm{U}-\mathrm{Pb}$ SHRIMP ages in zircons from the Agrio 


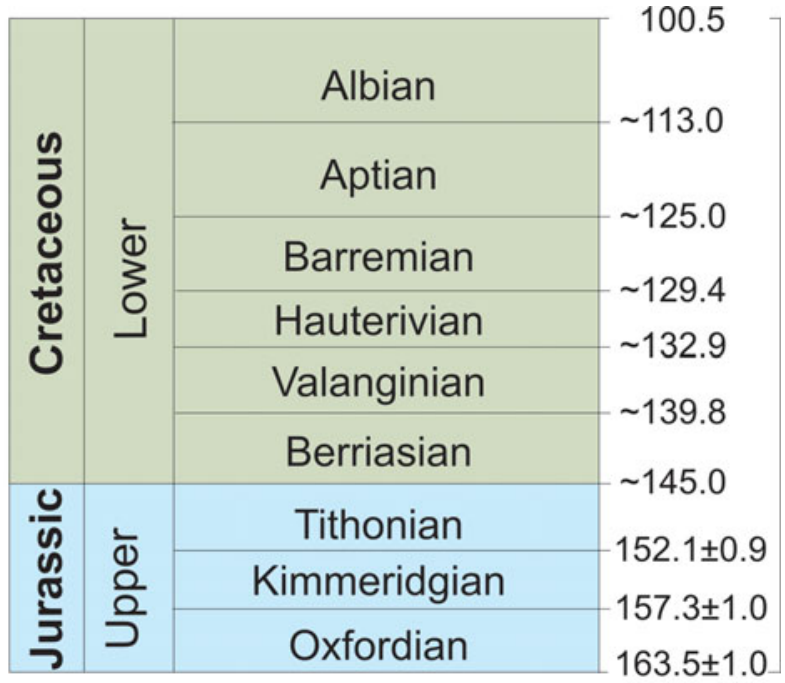

Figure 1. (Colour online) The 2013 Upper Jurassic - Lower Cretaceous geological time scale of the International Commission on Stratigraphy. Note that most of the numerical ages are approximate (from Cohen et al. 2013).

Formation to provide an isotopic date for the base of the Upper Hauterivian. Our new research follows the recommendations of Gradstein et al. (2012) to use the U-Pb CA-ID-TIMS zircon method to provide more precise age determinations for that level and for the Hauterivian/Barremian boundary.

\section{The geological setting}

The Agrio Formation (Weaver, 1931) covers extensive areas of the Neuquén Basin in west-central Argentina (Fig. 2a). It is up to $1300 \mathrm{~m}$ thick and is divided into three members (Leanza \& Hugo, 2001). Both the Pilmatué and Agua de la Mula members are marine, mainly composed of dark shales and paler, silty shales interbedded with limestones that contain an abundant invertebrate fauna. The middle Avilé Member is a 30-40 m thick package of yellowish coarse sandstones, often with cross-bedding of fluvial and aeolian origin (Gulisano \& Gutiérrez Pleimling, 1988). The Agrio Formation represents a storm-dominated, shallow-marine environment, with mixed siliciclastic and carbonate sedimentation (Brinkmann, 1994; Spalletti et al. 2001). Ammonoids and calcareous nannofossils together indicate that the formation is of late Early Valanginian to earliest Barremian age. Detailed ammonite zonation of the Neuquén Basin is based on Aguirre-Urreta \& Rawson (1997) with subsequent modifications in AguirreUrreta et al. (2005, 2007) and Aguirre-Urreta \& Rawson (2012). Nannofossil zones and events are documented by Bown \& Concheyro (2004) and Concheyro et al. (2009). Integration of the two zonal schemes is presented by AguirreUrreta et al. (2005) and Concheyro et al. (2009).

One of the key factors of the Agrio Formation is that it is associated with a volcanic arc that is mainly exposed in the Chilean slope of the Andean Cordillera at these latitudes. Jurassic-Cretaceous magmatic activity along the arc was clearly episodic (Parada et al. 2007; Morata et al. 2008). This calcalkaline volcanic activity, frequently of an explosive nature, shows pyroclastic pulses that peaked in Early Tithonian (Naipauer et al. 2014), Middle-Late Berriasian (Vennari et al. 2014) and Late Hauterivian (this study) times to reach a maximum in Aptian-Albian times (Charrier, Pinto $\&$ Rodríguez, 2007). These magmatic pulses may be related to the intermittent nature of the subduction and to variation in the convergence rates associated with migration and expansion of the volcanic front (Ramos, 2010; Folguera \& Ramos, 2011). Because the volcanism was intermittent there are only scattered ash-fall horizons within the Agrio Formation. In the study area, tuffs are very rare and thin in the Lower Hauterivian sequence but frequent in the Upper Hauterivian succession, in the Agua de la Mula Member. Two tuffs were sampled from this member, one at Caepe Malal and the other at Agrio del Medio, where two detailed partial sections were measured (Fig. 2c, d). A complete section through the member was studied at Mina San Eduardo, to provide a valuable reference section to which the two tuff-bearing sequences can be correlated (Fig. 2b).

\section{2.a. Mina San Eduardo section $\left(37^{\circ} 32^{\prime} 25^{\prime \prime} \mathrm{S}\right.$, $\mathbf{7 0}^{\circ} \mathbf{0 0}^{\prime} 22^{\prime \prime} \mathrm{W}$ )}

The Agua de la Mula Member reaches 475 m here (Fig. 2b) and is generally well exposed though partially covered in the middle. Fissile bluish-black shales at the base are followed by dark shales and paler silty shales with numerous levels of fossiliferous calcareous nodules. Up sequence the dark shales are interbedded at first with thin siltstones and floatstones, and then with more frequently intercalated fine calcareous sandstones and silty sandstones. The section ends with a $2 \mathrm{~m}$ thick, orange, hard calcareous siltstone. Ammonoids recovered from 43 horizons have been grouped into five biozones, from the Spitidiscus riccardii Biozone at the base up to the Sabaudiella riverorum Zone at the top. Calcareous nannofossils recovered from 72 horizons allowed the recognition of seven successive bioevents, consisting of the first common occurrence (FCO) of Clepsilithus maculosus, the first occurrence (FO) of Lithraphidites bollii, the last occurrence (LO) of Cruciellipsis cuvillieri, the FO of Nannoconus ligius and the LOs of Clepsilithus maculosus, N. ligius and L. bollii (Fig. 2b).

The basal levels record the FCO of Clepsilithus maculosus (BAFC-NP 1728), a species previously only recorded in the CC4-A (Eiffellithus striatus) Subzone in the Neuquén Basin (Aguirre-Urreta et al. 2005; Concheyro et al. 2009). In the section, this bioevent occurs in the Spitidiscus riccardii ammonite zone. The FO of L. bollii and LO of Cruciellipsis cuvillieri (BAFC-NP 1743) have been determined together in levels with Crioceratites schlagintweiti. These bioevents mark the lowest part of the CC4-B Subzone in the Neuquén Basin.

High in the diamantensis Zone, the FO of Nannoconus ligius (BAFC-NP 1777) indicates a level high in the Neuquén CC4-B Subzone. Further up the section, the LOs of C. maculosus (BAFC-NP 1783), L. bollii and N. ligius (BAFC-NP 1788) indicate the CC5 Zone.

\section{2.b. Caepe Malal section $\left(37^{\circ} 11^{\prime} \mathrm{S}, 7^{\circ} 23^{\prime} \mathrm{W}\right)$}

The succession in Caepe Malal extends from the top $15 \mathrm{~m}$ of the Pilmatué Member, through the Avilé ( $83 \mathrm{~m}$ ) and Agua de la Mula $(280 \mathrm{~m})$ members to the base of the Huitrín Formation. A partial section measured at the base of the Agua de la Mula Member (Fig. 2c) starts with c. $18 \mathrm{~m}$ of fissile dark bluish calcareous shales, in which a pale yellow vitric tuff, $1.2 \mathrm{~m}$ thick, is intercalated $7 \mathrm{~m}$ above the base and between two horizons yielding Spitidiscus characteristic of the $S$. riccardii Zone. The vitric tuff is formed almost exclusively by angular unwelded volcanic shards and exhibits low contents of quartz and plagioclase crystaloclasts; open spaces are filled by secondary carbonates. The succession continues with dark shales with impressions of Crioceratites sp. at two levels (Fig. 2c). Nannofossil assemblages in these and the 


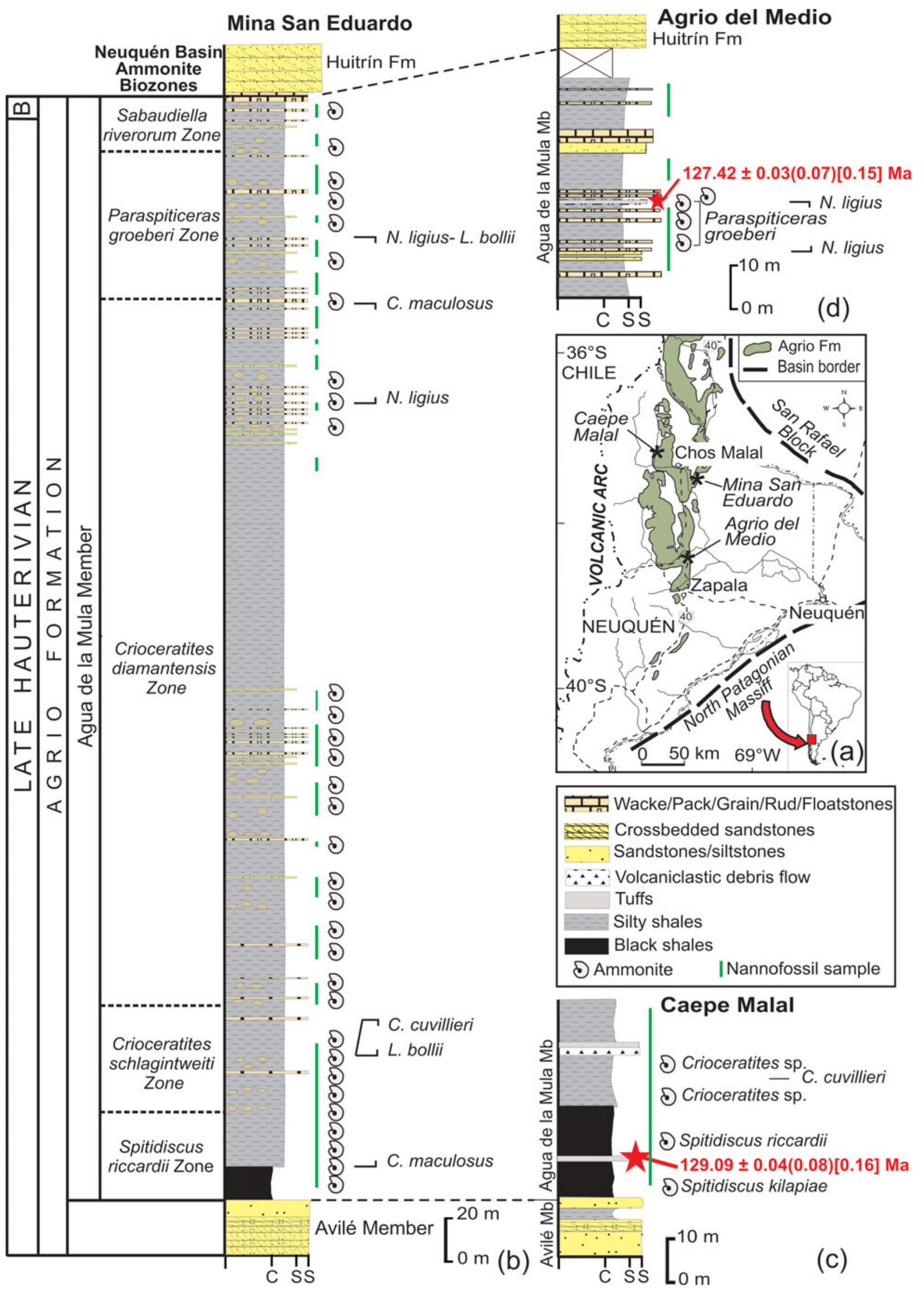

Figure 2. (Colour online) (a) The Neuquén Basin in west-central Argentina showing outcrops of the Agrio Formation, basin borders and location of studied localities. (b) Lithic log of the Agua de la Mula Member of the Agrio Formation in Mina San Eduardo with ammonoid zonation and nannofossil bioevents. B. - Barremian. (c) Lithic log of lower part of the Agua de la Mula Member in Caepe Malal with location of the tuff layer. (d) Lithic log of upper part of the Agua de la Mula Member in Agrio del Medio with location of the tuff layer. 
underlying shales are very poor and badly preserved, only characterized by the presence of $C$. cuvillieri (BAFC-NP 3119). Higher in the sequence, several subaqueous volcaniclastic debris-flow deposits occur interbedded in the dark shales. Zircons in the vitric tuff gave an age of $132.08 \pm 1.3 \mathrm{Ma}$ by U-Pb SHRIMP dating (Aguirre-Urreta et al. 2008), but we present here a new, more precise $\mathrm{U}-\mathrm{Pb}$ zircon age using the CA-ID-TIMS method (Section 3 below).

\section{2.c. Agrio del Medio section $\left(38^{\circ} 20^{\prime} \mathrm{S}, 69^{\circ} 57^{\prime} \mathrm{W}\right)$}

The Agua de la Mula Member here reaches $420 \mathrm{~m}$ in thickness. The topmost part of the section (Fig. 2d) starts with an orange oyster floatstone followed by a thick greenish shale package interbedded with thin fine ondulitic sandstones. Up sequence, greenish shales with thin fine sandstones include ten prominent levels of floatstones and rudstones with a highly diverse marine fauna (bivalves, ammonoids, serpulids, crinoids, sponges and gastropods) and one conspicuous, $15 \mathrm{~cm}$ thick, whitish vitric tuff dated here by the $\mathrm{U}-\mathrm{Pb}$ zircon CA-ID-TIMS method. In the vitric tuff, shards are the main component of the glass that it is highly altered to carbonate. Crystals are less than $10 \%$; angular quartz grains with engulfments and plagioclase are dominant, followed in abundance by biotite and K-feldspar. Volcanic lithic particles are rare and zircons are present as accessory minerals. Two channelized oolitic grainstones reveal the somerization of the succession. The grainstones are overlain by shales with another conspicuous bioclastic grainstone. The contact with the overlying Huitrín Formation is covered.

Ammonites characteristic of the Paraspiticeras groeberi Zone occur at four horizons, the highest just above the tuff level. Moderately preserved nannofossils have been recovered from ten horizons. Two bioevents, FO and LO of Nannoconus ligius (BAFC-NP 3940 and BAFC-NP 3943, respectively), have been recorded (Fig. 2d), both within the Paraspiticeras groeberi Zone. These bioevents occur in the CC4-B nannofossil subzone and CC5 nannofossil zone of the Neuquén Basin zonation, respectively.

\section{U-Pb CA-ID-TIMS results}

Abundant populations of relatively large (c. 100-300 microns in long dimension), elongate, prismatic zircon crystals were separated from both tuff hand samples by conventional density and magnetic methods. The entire zircon separate from each sample was placed in a muffle furnace at $900^{\circ} \mathrm{C}$ for 60 hours in quartz beakers to anneal minor radiation damage; annealing enhances cathodoluminescence (CL) emission and prepares the crystals for subsequent chemical abrasion (Mattinson, 2005). Following annealing, individual grains were hand-picked, mounted, polished and imaged by CL on a scanning electron microscope. From these compiled images, grains with consistent and dominant CL patterns were selected for further isotopic analysis (see Figs S1 \& S2 in the online Supplementary Material available at http://journals.cambridge.org/geo).

Selected crystals were plucked from grain mounts, chemically abraded using a single aggressive abrasion step in concentrated $\mathrm{HF}$ at $195^{\circ} \mathrm{C}$ for 12 hours, and the residual crystals processed for ID-TIMS. The details of ID-TIMS analysis are described by Davydov et al. (2010) and Schmitz \& Davydov (2012). U-Pb dates and uncertainties for each analysis were calculated using the algorithms of Schmitz \& Schoene (2007), the U decay constants of Jaffey et al. (1971) and values of ${ }^{235} \mathrm{U} /{ }^{205} \mathrm{~Pb}=100.2329$ and ${ }^{233} \mathrm{U} /{ }^{235} \mathrm{U}=0.99506$ for the ET535 tracer. Other details of analytical parameters can be
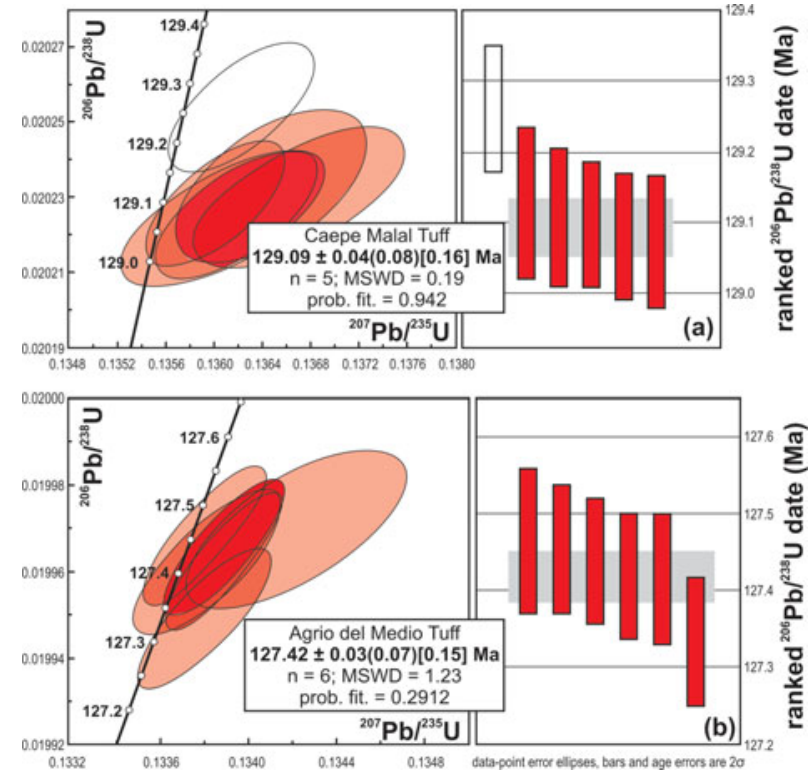

Figure 3. (Colour online) U-Pb CA-ID-TIMS data for chemically abraded zircons from the Agua de la Mula Member of the Agrio Formation (Concordia plots and mean ${ }^{206} \mathrm{~Pb}-{ }^{238} \mathrm{U}$ ages). (a) Caepe Malal tuff. (b) Agrio del Medio tuff.

found in the notes to Table S1 in the online Supplementary Material available at http://journals.cambridge.org/geo.

Propagated age uncertainties are based upon nonsystematic analytical errors, including counting statistics, instrumental fractionation, tracer subtraction and blank subtraction. These error estimates should be considered when comparing our ${ }^{206} \mathrm{~Pb}-{ }^{238} \mathrm{U}$ dates with those from other laboratories that used tracer solutions calibrated against the EARTHTIME gravimetric standards. When comparing our dates with those derived from other decay schemes (e.g. ${ }^{40} \mathrm{Ar}-{ }^{39} \mathrm{Ar},{ }^{187} \mathrm{Re}-{ }^{187} \mathrm{Os}$ ), the uncertainties in tracer calibration $(0.05 \%$; Condon et al. 2007) and U decay constants $(0.108 \%$; Jaffey et al. 1971$)$ should be added to the internal error in quadrature. Quoted errors for calculated weighted means are thus of the form $\pm \mathrm{X}(\mathrm{Y})[\mathrm{Z}]$, where $\mathrm{X}$ is solely analytical uncertainty, $Y$ is the combined analytical and tracer uncertainty, and $\mathrm{Z}$ is the combined analytical, tracer and ${ }^{238} \mathrm{U}$ decay constant uncertainty.

\section{3.a. Caepe Malal tuff}

CL-imaging of the 47 zircon crystals from the Caepe Malal tuff sample revealed a consistent population of moderately to brightly luminescent, oscillatory zoned crystals (Fig. S1 in the online Supplementary Material available at http://journals.cambridge.org/geo). A minority of crystals have irregularly shaped, uniform to complexly zoned cores overgrown by these luminescent, oscillatory rims. Six of the largest zircon grains were selected for CA-TIMS analysis on the basis of CL pattern (Table S1 in the online Supplementary Material available at http://journals.cambridge.org/geo). Five of the six analyses are concordant and equivalent, with a weighted mean ${ }^{206} \mathrm{~Pb}$ ${ }^{238} \mathrm{U}$ date of $129.09 \pm 0.04(0.08)[0.16] \mathrm{Ma}(\mathrm{MSWD}=0.19)$ (Fig. 3a), which is interpreted as dating the eruption and deposition of this tuff. A single crystal yielded a resolvable older ${ }^{206} \mathrm{~Pb}-{ }^{238} \mathrm{U}$ date of $129.26 \pm 0.09 \mathrm{Ma}$, which is interpreted to contain a small nucleus of inherited zircon in its core. 


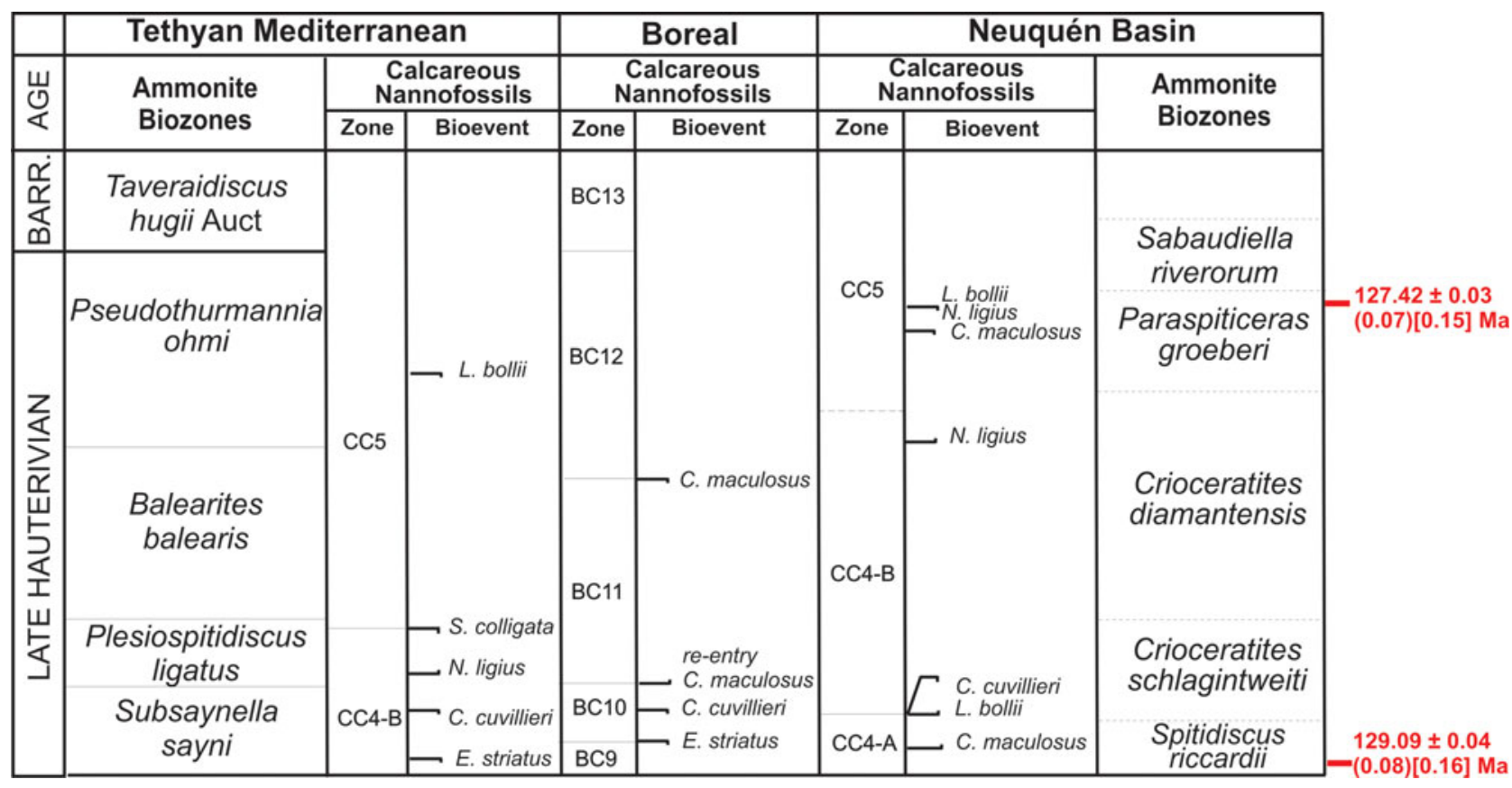

Figure 4. (Colour online) Late Hauterivian - Early Barremian chart with Tethyan Mediterranean and Neuquén ammonite zonation and the correlation with calcareous nannofossil bioevents and zones in the Mediterranean and Boreal realms and in the Neuquén Basin, with location of the new numerical U-Pb CA-ID-TIMS ages in red.

\section{3.b. Agrio del Medio tuff}

CL-imaging of the 74 largest zircon crystals from the Agrio del Medio tuff sample revealed a consistent population of moderately to brightly luminescent, oscillatory zoned crystals (Fig. S2 in the online Supplementary Material available at http://journals.cambridge.org/geo). A prominent thin non-luminescent (dark) zone occurs approximately two-thirds to three-quarters of the radius from the centre of most crystals. A lesser number of crystals have irregularly shaped, relatively non-luminescent cores overgrown by the luminescent, oscillatory rims. Six grains were selected for CA-TIMS analysis on the basis of the uniform, predominant CL pattern, avoiding those crystals with resorbed non-luminescent cores. All six analyses are concordant and equivalent, with a weighted mean ${ }^{206} \mathrm{~Pb}-{ }^{238} \mathrm{U}$ date of $127.42 \pm 0.03(0.07)[0.15]$ Ma (MSWD $=1.23$ ) (Fig. 3b), which is interpreted as dating the eruption and deposition of this tuff.

\section{Correlation of tuff horizons with the Tethyan 'standard'}

Ammonite evidence places both tuff horizons firmly within the Neuquén Basin ammonite zonation: the lower tuff lies just above the base of the Spitidiscus riccardii Zone and the upper is high in the Paraspiticeras groeberi Zone. Correlation of the Neuquén ammonite zonation with the West Mediterranean zonal scheme of the Tethyan Realm, which is taken as the 'standard', was discussed by Aguirre-Urreta \& Rawson in Reboulet et al. (2014) and their Late Hauterivian to earliest Barremian correlation is summarized in Figure 4. The base of the Spitidiscus riccardii Zone is correlated with the base of the Subsaynella sayni Zone, which marks the base of the Upper Hauterivian. The Paraspiticeras groeberi Zone is correlated with part of the highest Hauterivian Pseudothurmannia ohmi Zone.

Calcareous nannofossil records support this correlation. Combining the calcareous nannofossil records from the Mina
San Eduardo, Caepe Malal and Agrio del Medio sections, seven bioevents have been identified through the Agua de la Mula Member. Most of these correspond to bioevents that have been used to construct the Mediterranean zonation of the Tethyan Realm (Sissingh, 1977; Applegate \& Bergen, 1988). However, the FO and LO of Clepsilithus maculosus, considered Boreal bioevents (Rutledge \& Bown, 1996) are also recognized here and elsewhere in the Neuquén Basin (Fig. 4) (see selected nannofossil species in Fig. S3 in the online Supplementary Material available at http://journals.cambridge.org/geo).

From the seven bioevents recognized, three of them are discussed here, the FO and LO of Lithraphidites bollii and the LO of Cruciellipsis cuvillieri. Lithraphidites bollii, a consistent marker, has been found in several Mediterranean sections and oceanic boreholes, allowing valuable correlations (e.g. Cecca et al. 1994; Sprovieri et al. 2006; Aguado et al. 2014). Applegate \& Bergen (1988) used the FO of L. bollii as a marker for the base of CC4-A. The CC4-A and CC4B boundary has been considered Early Hauterivian in the Tethyan Realm, and has been correlated with the Crioceratites loryi ammonite zone (Bergen, 1994) and with Polarity Chron CM9 (Ogg \& Hinnov, 2012b). However, in several sections of the Neuquén Basin, the FO of $L$. bollii occurs at a higher level, near the base of the Upper Hauterivian (AguirreUrreta et al. 2005). The LO of L. bollii has been used as a reliable marker within the $\mathrm{CC} 5$ Zone. In the Tethyan region, it occurs within the Pseudothurmannia ohmi ammonite zone (Bergen, 1994), at the top of the Hauterivian (Aguado et al. 2014; Reboulet et al. 2014) and within the Polarity Chron CM5 (Ogg \& Hinnov, 2012b). In the Neuquén Basin, this bioevent is recorded high in the Agua de la Mula Member, in beds included in the Paraspiticeras groeberi ammonite zone, which in turn is correlated with part of the Pseudothurmannia ohmi Zone (Fig. 4).

The LO of Cruciellipsis cuvillieri has been used as a global marker for the Early-Late Hauterivian boundary (Bralower et al. 1995; Mutterlose et al. 1996; Ogg, Agterberg \& Gradstein, 2004). In the Tethyan Realm, this bioevent is associated 
with the LO of E. striatus (Ogg, Ogg \& Gradstein, 2008) in the middle part of the Subsaynella sayni ammonite zone (Bergen, 1994) close to the base of CM8r in Italy (Channell et al. 1995; Channell, Cecca \& Erba, 1995). As the S. sayni Zone has not been recognized in the Boreal Realm, the LO of $C$. cuvillieri has proved to be an important link between both realms. However, in the Boreal Realm both bioevents (LO of C. cuvillieri and LO de E. striatus) occur in the Upper Hauterivian (Bown et al. 1998). In the Neuquén Basin, the LO of Cruciellipsis cuvillieri is at the base of the Crioceratites schlagintweiti Zone (Aguirre-Urreta et al. 2005) of early Late Hauterivian age.

\section{Discussion: significance of the new dates}

In a seminal paper published 40 years ago, Baldwin, Coney $\&$ Dickinson (1974) discussed the dilemma of the Cretaceous time scale and sea-floor spreading rates. Their main conclusion was that Cretaceous spreading rates could not be finally established until the Cretaceous time scale was more precisely calibrated to numerical time. Several attempts in recent years to calibrate the magnetic time scale for the Late Jurassic - Early Cretaceous have failed, either for lack of precise ages from altered oceanic floor basalts, or for poor biostratigraphic control of these oceanic sequences (Mahoney et al. 2005).

We present here two robust ages tied with precise calcareous nannofossil bioevents and ammonites of Late Hauterivian age in the Neuquén Basin. The first one, of $129.09 \pm 0.04(0.08)[0.16] \mathrm{Ma}$, is from a tuff level only $7 \mathrm{~m}$ above the base of the Upper Hauterivian sequence, so we can place with some confidence the Early-Late Hauterivian boundary at $129.5 \mathrm{Ma}$. This age is very close to that proposed by Channell et al. (1995) and Channell, Cecca \& Erba (1995) based on direct correlation of ammonite biozones and land section magnetostratigraphy, together with radiometric ages. It is much older than the data published by Fiet et al. (2006) who bracketed the Hauterivian between $123.6 \pm 1.7 \mathrm{Ma}$ and $118.3 \pm 1.7 \mathrm{Ma}$ based on $\mathrm{K}-\mathrm{Ar}$ dating of glauconite combined with orbital chronology. It also differs markedly from Ogg \& Hinnov's (2012a) placement of this boundary at $133 \mathrm{Ma}$. It should be noted here that in their figure 27.6 these authors misplaced the Early-Late Hauterivian boundary in the middle of the Balearites balearis Zone instead of at the base of the Subsaynella sayni Zone as internationally accepted (Reboulet et al. 2011, 2014).

Our second age, of $127.42 \pm 0.03(0.07)[0.15] \mathrm{Ma}$, is from a tuff level that correlates with the upper part of the Pseudothurmannia ohmi Zone and is therefore close to the top of the Hauterivian. So we suggest the Hauterivian/Barremian boundary is around $127 \mathrm{Ma}$. Again our datum is much older than that of Fiet et al. (2006) who placed that boundary at $118.3 \pm 1.7 \mathrm{Ma}$, but younger than the ages of Ogg \& Hinnov (2012a) and Cohen et al. (2013) who placed the top Hauterivian at $130.8 \mathrm{Ma}$ and $\sim 129.4 \mathrm{Ma}$, respectively.

The new data presented here imply moving the base of the Barremian by 3 to $4 \mathrm{Ma}$ in comparison with Gradstein et al.'s (2012) and the International Commission on Stratigraphy's (ICS) time scale. However, this displacement is comparable with Vennari et al.'s (2014) placement of the base of the Cretaceous at $140 \mathrm{Ma}, 5$ million years younger than on the present ICS 2013 time scale. Their work is also based on a U$\mathrm{Pb}$ CA-ID-TIMS numerical age combined with nannofossil and ammonite biostratigraphy of the Neuquén Basin.

Our new ages also support the proposal of He et al. (2008) who dated the M0r, which is presently taken as marking the base of the Aptian, to $121.2 \pm 0.5 \mathrm{Ma}$ by ${ }^{40} \mathrm{Ar}-{ }^{39} \mathrm{Ar}$ dating. This is very important because the age of the M0r has been used as a key point to construct the Early Cretaceous magnetic polarity time scale and to estimate the Pacific Ocean spreading rates.

These results are also relevant for the stratigraphy of the Agua de la Member of the Agrio Formation. The two age dates indicate a sedimentation rate ranging from $170 \mathrm{~m} / \mathrm{Ma}$ to $190 \mathrm{~m} / \mathrm{Ma}$ in the eastern part of the basin (Agrio del Medio and Mina San Eduardo localities, respectively) and $110 \mathrm{~m} / \mathrm{Ma}$ in the northwest (Caepe Malal section). These sedimentation rates are consistent with a mixed siliciclasticcarbonate ramp setting and higher than those of pure siliciclastic shelves (Einsele, 2000).

In conclusion, our two new radioisotopic ages-129.5 Ma for the base of the Late Hauterivian and $127 \mathrm{Ma}$ for the base of the Barremian - support the proposal of Channell et al. (1995), Channell, Cecca \& Erba (1995) and He et al. (2008) to date the base of the Aptian around $121 \mathrm{Ma}$ and that of Vennari et al. (2014) to move up the base of the Berriasian to $140 \mathrm{Ma}$. Investigations in progress will hopefully provide more robust data in order to improve the numerical dating of the Berriasian and Valanginian in the marine succession of the Argentine Andes.

Acknowledgements. We are grateful to S. Adamonis, D. Lazo, E. Ottone and P. Pazos (UBA) for their help in the field. This work was supported by CONICET (V.A.R. PIP 509), ANPCYT (B.A.U. PICT 0464/10), UBACYT (V.A.R. 09523, B.A.U. 09678). This is contribution R-139 of the Instituto de Estudios Andinos Don Pablo Groeber (UBACONICET).

\section{Supplementary materials}

To view the Supplementary Material for this article, please visit http://dx.doi.org/10.1017/S001675681400082X

\section{References}

Aguado, R., COMPANY, M., O'DOgherty, L., SANDOVAL, J. \& TAVERA, J. M. 2014. Late Hauterivian-early Barremian calcareous nannofossil biostratigraphy, palaeoceanography, and stable isotope record in the Subbetic domain (southern Spain). Cretaceous Research 49 , $105-24$.

Aguirre-Urreta, M. B., Mourgues, F. A., Rawson, P. F., Bulot, L. G. \& JAILlaRd, E. 2007. The Lower Cretaceous Chañarcillo and Neuquén Andean basins: ammonoid biostratigraphy and correlations. Geological Journal 42, 143-73.

Aguirre-Urreta, M. B., PAZos, P. J., LAZO, D. G., FANNING, C. M. \& LITVAK, V. D. 2008. First U-Pb SHRIMP age of the Hauterivian stage, Neuquén Basin, Argentina. Journal of South American Earth Sciences 26, 91-9.

Aguirre-URreta, M. B. \& RAWSON, P. F. 1997. The ammonite sequence in the Agrio Formation (Lower Cretaceous), Neuquén basin, Argentina. Geological Magazine 134, 449-58.

Aguirre-Urreta, M. B. \& Rawson, P. F. 2012. Lower Cretaceous ammonites from the Neuquén Basin, Argentina: a new heteromorph fauna from the uppermost Agrio Formation. Cretaceous Research 35, 208-16.

Aguirre-Urreta, M. B., Rawson, P. F., Concheyro, G. A., Bown, P. R. \& OTTONE, E. G. 2005. Lower Cretaceous biostratigraphy of the Neuquén Basin. In The Neuquén Basin: A Case Study in Sequence Stratigraphy and Basin Dynamics (eds G. Veiga, L. Spalletti, J. A. Howell \& 
E. Schwarz), pp. 57-81. Geological Society of London, Special Publication no. 252.

Applegate, J. \& Bergen, J. 1988. Cretaceous calcareous nannofossil biostratigraphy of sediments recovered from the Galicia Margin, ODP Leg 103. In Proceedings of the Ocean Drilling Project, Scientific Results, vol. 103 (eds G. Boillot, E. L. Winterer, A. W. Meyer, et al.), pp. 293346. College Station, Texas.

Baldwin, B., Coney, P. J. \& Dickinson, W. R. 1974. Dilemma of a Cretaceous time scale and rates of sea-floor spreading. Geology 1974 (2), 267-70.

BERGEN, J. A. 1994. Berriasian to Early Aptian calcareous nannofossils from the Vocontian Trough (SE France) and Deep Sea Drilling Site 534: new nannofossil taxa and a summary of low-latitude biostratigraphic events. Journal of Nannoplankton Research 16, 59-69.

Bown, P. R. \& Concheyro, A. 2004. Lower Cretaceous calcareous nannoplankton from the Neuquén Basin, Argentina. Marine Micropaleontology 52, 51-84.

Bown, P. R., Rutledge, D. C., CRuX, J. A. \& Gallagher, L. T. 1998. Lower Cretaceous. In Calcareous Nannofossil Biostratigraphy (ed. P. R. Bown), pp. 86-131. British Micropalaeontology Society Publication Series. London: Chapman \& Hall.

Bralower, T. J., LeCKIE, R. M., Sliter, W. V. \& ThiERSTEIN, H. R. 1995. An integrated Cretaceous microfossil biostratigraphy. In Geochronology, Time Scales and Global Stratigraphic Correlation (eds W. A. Berggren, D. V. Kent, M.-P. Aubry \& J. Hardenbol), pp. 65-79. Society of Economic Paleontologists and Mineralogists, Special Publication no. 54.

BrinkmanN, H. D. 1994. Facies and sequences of the Agrio Formation (Lower Cretaceous) in the central and southern Neuquén Basin, Argentina. Zentralblatt für Geologie und Palaeontologie 1, 309-17.

Cecca, F., Pallini, G., Erba, E., Premoli-Silva, I. \& CoccionI, R. 1994. Hauterivian-Barremian chronostratigraphy based on ammonites, nannofossils, planktonic foraminifera and magnetic chrons from the Mediterranean domain. Cretaceous Research 15, 457-67.

Channell, J. E. T., Casellato, C. E., Muttoni, G. \& ERBA, E. 2010. Magnetostratigraphy, nannofossil stratigraphy and apparent polar wander for Adria-Africa in the Jurassic-Cretaceous boundary interval. Palaeogeography, Palaeoclimatology, Palaeoecology 293, 5175.

Channell, J. E. T., CeccA, F. \& Erba, E. 1995. Correlations of Hauterivian and Barremian (Early Cretaceous) stage boundaries to polarity chrons. Earth and Planetary Science Letters 134, 125-40.

Channell, J. E. T., ERBA, E., NAKanishi, M. \& TAmaki, K. 1995. Late Jurassic-Early Cretaceous time scales and oceanic magnetic anomaly block models. In Geochronology Time Scales and Global Stratigraphic Correlation (eds W. A. Berggren, D. V. Kent, M.-P. Aubry \& J. Hardenbol), pp. 51-63. Society of Economic Paleontologists and Mineralogists, Special Publication no. 54.

Charrier, R., Pinto, L. \& Rodríguez, M. P. 2007. Tectonostratigraphic evolution of the Andean Orogen in Chile. In The Geology of Chile (eds T. Moreno \& W. Gibbons), pp. 21-114. London: The Geological Society.

CohEn, K. M., Finney, S. C., GibBARD, P. L. \& FAN, J.-X. 2013. The ICS International Chronostratigraphic Chart. Episodes 36, 199-204.

Concheyro, A., Lescano, M., Caramés, A. \& Ballent, S. 2009. Micropaleontología de la Formación Agrio (Cretácico inferior) en distintos sectores de la cuenca
Neuquina, Argentina. Revista de la Asociación Geológica Argentina 65, 342-61.

Condon, D., Schoene, B., Bowring, S., Parrish, R., MCLEAN, N., Noble, S. \& CROWLEY, Q. 2007. EARTHTIME; isotopic tracers and optimized solutions for highprecision U-Pb ID-TIMS geochronology. Eos, Transactions of the American Geophysical Union 88 (52), Fall Meeting Supplement, Abstract V41E-06.

DaVydov, V. I., CROWley, J. L., SChMitz, M. D. \& PoletaeV, V. I. 2010. High-precision U-Pb zircon age calibration of the global Carboniferous time scale and Milankovitchband cyclicity in the Donets Basin, eastern Ukraine. Geochemistry, Geophysics, Geosystems 11, Q0AA04, doi: 10.1029/2009GC002736.

EInsele, G. 2000. Sedimentary Basins, Evolution, Facies and Sediment Budget. Berlin: Springer-Verlag, 792 pp.

Fiet, N., Quidelleur, X., Parize, O., Bulot, L. G. \& GILLOT, P. Y. 2006. Lower Cretaceous stage durations combining radiometric data and orbital chronology: towards a more stable relative time scale? Earth and Planetary Science Letters 246, 407-17.

Folguera, A. \& RAmos, V. A. 2011. Repeated eastward shifts of arc magmatism in the southern Andes: a revision to the long-term pattern of Andean uplift and magmatism in the southern Andes. Journal of South American Earth Sciences 32, 530-45.

Gradstein, F. M., OGG, J. G., Schmitz, M. D. \& OGG, G. M. 2012. The Geologic Time Scale 2012. Amsterdam: Elsevier, $1144 \mathrm{pp}$.

Gulisano, C. A. \& Gutiérrez Pleimling, A. 1988. Depósitos eólicos del Miembro Avilé (Formación Agrio, Cretácico inferior) en el norte del Neuquén, Argentina. Actas Segunda Reunión Argentina de Sedimentología 1, $120-4$.

He, H. Y., Pan, Y. X., TauXe, L., Qin, H. F. \& Zhu, R. X. 2008. Toward age determination of the M0r (BarremianAptian boundary) of the Early Cretaceous. Physics of the Earth and Planetary Interiors 169, 41-8.

Jaffey, A. H., Flynn, K. F., Glendenin, L. E., Bentley, W. C. \& Essling, A. M. 1971. Precision measurements of half-lives and specific activities of ${ }^{235} \mathrm{U}$ and ${ }^{238} \mathrm{U}$. Physical Review C 4, 1889-906.

LeanzA, H. A. \& HugO, C. 2001. Hoja Geológica Zapala, Hoja 3969-I, 1:250.000. Boletín del Instituto de Geología y Recursos Minerales 275, 1-128.

LIU, Y. Q., Ji, Q., JIANG, X.-J., KUANG, H.-W., JI, S., GAO, L.F., ZhANG, Z.-G., PENG, N., YUAN, CH.-X., WANG, X.-R. \& XU, H. 2013. U-Pb zircon ages of Early Cretaceous volcanic rocks in the Tethyan Himalaya at Yangzuoyong Co Lake, Nagarze, Southern Tibet, and implications for the Jurassic/Cretaceous boundary. Cretaceous Research 40, 90-101.

Mahoney, J. J., Duncan, R. A., TejadA, M. L. G., SAgER, W. W. \& BRALOWER, T. J. 2005. Jurassic-Cretaceous boundary age and mid-ocean-ridge-type mantle source for Shatsky Rise. Geology 33, 185-8.

MATTINSON, J. M. 2005. Zircon U-Pb chemical abrasion ("CA-TIMS") method: combined annealing and multistep partial dissolution analysis for improved precision and accuracy of zircon ages. Chemical Geology 220, 47-66.

Morata, D., Féraud, G., Aguirre, L., Arancibia, G., Belmar, M., Morales, S. \& CARrillo, J. 2008. Geochronology of the Lower Cretaceous volcanism from the Coastal Range at the $29^{\circ} 20^{\prime}-30^{\circ} \mathrm{S}$, Chile. Revista Geológica de Chile 35, 123-45.

Mutterlose, J. C., Autran, G., Baraboschinin, E. J., Cecca, F., Erba, E., Gardin, S., Herngren, 
H., Hoedemaker, P., Kakabadze, M., Klein, J., LEEREVELD, H., RAWSON, P. F., ROPOLO, P., VASICEK, Z. $\&$ VON SALIS, K. 1996. The Hauterivian Stage. Bulletin de L'Institut Royal des Sciences Naturelles de Belgique 66 (Supplement), 19-24.

Naipauer, M., Tunik, M., Marques, J. C., Rojas Vera, E. A., Vujovich, G. I., Pimentel, M. M. \& Ramos, V. A. 2014. U-Pb detrital zircon ages of Upper Jurassic continental successions: implications for the provenance and absolute age of the Jurassic-Cretaceous boundary in the Neuquén Basin. In Geodynamic Processes in the Andes of Central Chile and Argentina (eds S. Sepúlveda, L. Giambiagi, L. Pinto, S. Moreiras, M. Tunik, G. Hoke \& M. Farías). Geological Society of London, Special Publication no. 399. Published online 4 March 2014. doi: 10.1144/SP399.1.

OgG, J. G., Agterberg, F. P. \& Gradstein, F. M. 2004. The Cretaceous Period. In A Geologic Time Scale (eds F. Gradstein, J. G. Ogg \& A. Smith), pp. 344-83. Cambridge: Cambridge University Press.

OGg, J. G. \& HinNov, L. A. 2012a. The Cretaceous Period. In The Geologic Time Scale 2012 (eds F. Gradstein, J. G. Ogg, M. D. Schmitz \& G. M. Ogg), pp. 793-853. Amsterdam: Elsevier.

OGG, J. G. \& Hinnov, L. A. 2012b. The Jurassic Period. In The Geologic Time Scale 2012 (eds F. Gradstein, J. G. Ogg, M. D. Schmitz \& G. M. Ogg), pp. 731-91. Amsterdam: Elsevier.

OgG, J. G., OGG, G. \& Gradstein, F. 2008. The Concise Geologic Time Scale. Cambridge: Cambridge University Press, $177 \mathrm{pp}$.

Parada, M. A., LóPez-Escobar, L., Oliveros, V., Fuentes, F., Morata, D., CALderón, M., Aguirre, L., FÉraud, G., Espinoza, F., Moreno, H., Figueroa, O., Muñoz-Bravo, J., Troncoso VÁsquez, R. \& Stern, C. R. 2007. Andean magmatism. In The Geology of Chile (eds T. Moreno \& W. Gibbons), pp. 115-46. London: The Geological Society.

Ramos, V. A. 2010. The tectonic regime along the Andes: present settings as a key for the Mesozoic regimes. Geological Journal 45, 2-25.

Reboulet, S., Rawson, P. F., Moreno-Bedmar, J. A., Aguirre-Urreta, M. B., Barragan, R., Bogomolov, Y., COMPANY, M., GONZALEZ-ARREOLA, C., Stoyanova, V. I., LuKeneder, A., Matrion, B., Mitta, V., Randrianaly, H., VasiceK, Z., BARABOSHKIN, E. J., BERT, D., BERSAC, S., Bogdanova, T. N., Bulot, L. G., LATIL, J.-L., MikhailoVA, I. A., Ropolo, P. \& SzIVES, O. 2011. Report on the 4th International Meeting of the IUGS Lower Cretaceous Ammonite Working Group, the "Kilian Group" (Dijon, France, 30th August 2010). Cretaceous Research 32, 786-93.

Reboulet, S., Szives, O., Aguirre-Urreta, B., BARRAGÁN, R., COMPANY, M., IDAKIEVA, V., IVANOV,
M., Kakabadze, M. V., Moreno-Bedmar, J. A., SANDOVAl, J., BARABOShKin, E. J., ÇAGLAR, M. K., Fözy, I., GonzÁlez-Arreola, C., Kenjo, S., LuKENEDER, A., Raisossadat, S. N., RaWson, P. F. \& TAVERA, J. M. 2014. Report on the $5^{\text {th }}$ International Meeting of the IUGS Lower Cretaceous Ammonite Working Group, the "Kilian Group" (Ankara, Turkey, $31^{\text {st }}$ August 2013). Cretaceous Research 50, 126-37.

Rutledge, D. \& Bown, P. R. 1996. New names for old: taxonomic clarification of some Early Cretaceous nannofossil marker-species. Journal of Nannoplankton Research 18, 53-9.

SchMITZ, M. D. \& DAVYDOV, V. I. 2012. Quantitative radiometric and biostratigraphic calibration of the global Pennsylvanian - Early Permian time scale. Geological Society of America Bulletin 124, 549-77.

Schmitz, M. D. \& Schoene, B. 2007. Derivation of isotope ratios, errors and error correlations for $\mathrm{U}-\mathrm{Pb}$ geochronology using ${ }^{205} \mathrm{~Pb}^{235} \mathrm{U}-\left({ }^{233} \mathrm{U}\right)$-spiked isotope dilution thermal ionization mass spectrometric data. Geochemistry, Geophysics, Geosystems 8, Q08006, doi: 10.1029/2006GC00149.

SissinGH, W. 1977. Biostratigraphy of Cretaceous calcareous nannoplankton. Geologie en Mijnbouw 56, 37-65.

Spalletti, L. A., Poire, D., Pirrie, D., Matheos, S. \& DOYLE, P. 2001. Respuesta sedimentológica a cambios en el nivel de base en una secuencia mixta clásticacarbonática del Cretácico Inferior de la cuenca Neuquina, Argentina. Revista Sociedad Geológica de España 14, 57-74.

Sprovieri, M., Coccioni, R., Lirer, F., Pelosi, N. \& LOZAR, F. 2006. Orbital tuning of a lower Cretaceous composite record (Maiolica Formation, central Italy). Paleoceanography 21, PA4212, doi: 10.1029/005PA001224.

VenNari, V. V., Lescano, M., NAIPAUER, M., AgUiRreUrreta, B., Concheyro, A., SchaltegGer, U., Armstrong, R., Pimentel, M. \& RAmos, V. A. 2014. New constraints on the Jurassic-Cretaceous boundary in the High Andes using high-precision U-Pb data. Gondwana Research 26, 374-85.

Wan, X., Scott, R., Chen, W., GaO, L. \& Zhang, Y. 2011. Early Cretaceous stratigraphy and SHRIMP U$\mathrm{Pb}$ age constrain the Valanginian-Hauterivian boundary in southern Tibet. Lethaia 44, 231-44.

WEAVER, C. E. 1931. Paleontology of the Jurassic and Cretaceous of West Central Argentina. Memoir of the University of Washington 1, 1-469.

Wimbledon, W. A. P., Casellato, C. E., Reháková, D., Bulot, L. C., Erba, E., Gardin, S., Verreussel, R. M., Munsterman, D. K. \& Hunt, C. O. 2011. Fixing a basal Berriasian and Jurassic-Cretaceous (J-K) boundary - is there perhaps some light at the end of the tunnel? Rivista Italiana di Paleontologia e Stratigrafia 117, 295-307. 